\title{
Characteristics and Drug Resistance of Pathogens in Urinary Tract Infection Patients Complicated with Urinary Calculi
}

\author{
ZHENG GANG. LUO, XIANG RONG. YING, CHONG. SHEN, YI. REN, SHAO BO. WANG AND GANG FENG. WU*
}

Department of Urology, Shaoxing People's Hospital, No. 568 Zhongxing North Road, Shaoxing, Zhejiang 312000, China

Luo et al.: Drug resistance pathogens in patients with urinary calculi

Main objective is to explore the characteristics, drug resistance, and risk factors of pathogens in urinary tract infection patients complicated with urinary calculi. A total of 417 patients with urinary calculi who were treated in our hospital from January 2017 to December 2019 were enrolled in this study, including 234 patients with urinary tract infection and 183 patients without urinary tract infection. The midstream urine of 234 patients with urinary tract infection were cultured and used in the drug sensitivity test. Univariate and multivariate logistic regression analysis was used to analyze the risk factors of postoperative urinary tract infection in patients with urinary calculi. A total of 624 strains of pathogens were isolated from the urine samples of 234 patients with postoperative urinary tract infection, of which 386 strains were gram-negative bacteria $(61.86 \%), 169$ strains were gram-positive bacteria $(27.08 \%)$, and 69 strains were fungus (11.06 \%). In the drug resistance test, the resistance rates of Staphylococcus aureus to tetracycline, rifampicin, and levofloxacin, and the resistance rate of Enterococcus faecium to levofloxacin was low. Enterococcus faecalis had the lowest resistance rate to levofloxacin, followed by azithromycin and gentamicin. The resistance rates of Staphylococcus epidermidis to levofloxacin and vancomycin were low and the resistance rate to erythromycin was $100.00 \%$. The resistance rate of Acinetobacter baumannii, Escherichia coli, Pseudomonas aeruginosa, and Proteus mirabilis to meropenem and amikacin, and the resistance rate of Klebsiella pneumoniae and Proteus mirabilis to etilmicin and ceftriaxone were low. 
www.ijpsonline.com

Univariate analysis showed that the postoperative urinary tract infection in patients with urinary calculi was related to the age, operation time, postoperative indwelling catheter time, stone size, and preoperative prophylactic use of antibiotics. Multivariate logistic regression analysis showed that the age ( $\geq 65 \mathrm{y}$ old), operation time ( $\geq 60 \mathrm{~min})$, postoperative indwelling catheter time $(\geq 7 \mathrm{~d})$, and no preoperative prophylactic use of antibiotics were the risk factors of postoperative urinary tract infection in patients with urinary calculi. Patients with urinary calculi were prone to urinary tract infection after the operation. The main pathogens of infection were gram-negative bacteria and gram-positive bacteria, and they were resistant to some antibiotics. Antibiotics should be treated reasonably according to the risk factors of urinary tract infection and the results of the drug sensitivity tests to avoid further aggravation of bacterial drug resistances

Key words: Urinary calculi, urinary tract infection, pathogenic bacteria, drug resistance, risk factors

Urinary infection was an inflammation caused by the bacteria directly invading the urinary tract. Both urinary tract obstruction and reflux can cause abnormal changes in urodynamics, resulting in the poor urinary drainage and retention in the urinary tract, which was easy to cause infection. Urinary infection was a common infectious disease in the clinic, which was the second largest infectious disease in the world, and its incidence was second only to the respiratory tract infection ${ }^{[1,2]}$. There were many factors causing the urinary infection, including the decrease of immune function, postoperative catheter indwelling, and complicated with diabetes, urinary calculi ${ }^{[3-5]}$. With the progress of modern technology, minimally invasive surgery was widely used in the treatment of urinary calculi. However, the postoperative catheter indwelling often caused the urinary tract infection ${ }^{[6]}$. Due to the urinary tract infection seriously affects the recovery of postoperative prognosis and perioperative infection, and the unreasonable use or abuse of antibiotics in many hospitals, the drug resistance pathogens had been seriously threatened the patients ${ }^{[7,8]}$. Therefore, it is of great significance for clinical diagnosis and treatment to further understand the characteristics and drug resistance of pathogens in urinary tract infection patients complicated with urinary calculi. This study aims to explore the characteristics and drug resistance of pathogens in urinary tract infection patients complicated with urinary calculi, thus to providing a reliable basis for the diagnosis and treatment of urinary tract infection ${ }^{[9]}$.

A total of 417 patients with urinary calculi who were treated in our hospital from January 2017 to December 2019 were analyzed retrospectively, including 234 patients with urinary tract infection and

*Address for correspondence

E-mail: gaffwu@sina.com

September-October 2020
183 patients without urinary tract infection. The midstream urine of 234 patients with urinary tract infection was cultured and used in the drug sensitivity test. A total of 624 strains of pathogens were successfully isolated from urine.

The isolation, culture, and identification of the pathogens follow the "The National Clinical Test Regulation of Operation".

Biomerieux VITEK 2 Compact was used in the isolation and identification of the pathogens. The quantitative culture standard: gram-positive bacteria $\left(10^{4}\right.$ colonyforming units per milliliter-(CFU/ml)), gram-negative bacteria $\left(10^{5} \mathrm{CFU} / \mathrm{ml}\right)$, and fungus $\left(10^{4} \mathrm{CFU} / \mathrm{ml}\right)$.

Biomerieux VITEK 2 Compact automatic microbial identification and drug sensitivity system was used in bacterial identification, drug sensitivity test, and fungus identification, and Biomerieux ATB Expression was used in fungus drug sensitivity test. All the experiments were in accordance with the rules and standards in the Clinical and Laboratory Standards Institute (CLSI), and the results of the drug sensitivity were further judged.

All the data were analyzed by WHONET 5.6 software, and the rates were compared by Statistical Package for Social Sciences (SPSS) 21.0 analysis, $\mathrm{p}<0.05$ means the difference was statistically significant.

Among the isolated 624 strains of pathogens, gramnegative bacteria accounted for $61.86 \%$ (386), grampositive bacteria accounted for $27.08 \%$ (169), and

This is an open access article distributed under the terms of the Creative Commons Attribution-NonCommercial-ShareAlike 3.0 License, which allows others to remix, tweak, and build upon the work non-commercially, as long as the author is credited and the new creations are licensed under the identical terms

Accepted 25 October 2020

Revised 09 September 2020

Received 17 July 2020

Indian J Pharm Sci 2020;82(5):922-927 
fungus accounted for $11.06 \%$ (69). The composition of the flora was shown in Table 1.

In the drug resistance test, the resistance rates of Staphylococcus aureus to tetracycline, rifampicin, and levofloxacin were low, and the resistance rate of Enterococcus faecium to levofloxacin was low. Enterococcus faecalis had the lowest resistance rate to levofloxacin, followed by azithromycin and gentamicin. The resistance rates of Staphylococcus epidermidis to levofloxacin and vancomycin were low and the resistance rate to erythromycin was $100.00 \%$ (Table 2).

The resistance rate of Acinetobacter baumannii, Escherichia coli, Pseudomonas aeruginosa, and Proteus mirabilis to meropenem and amikacin were low. The resistance rate of Klebsiella pneumoniae and Proteus mirabilis to etilmicin and ceftriaxone were low (Table 3).

Univariate analysis was used to explore the risk factors of postoperative urinary tract infection in patients with urinary calculi. Univariate analysis showed that the postoperative urinary tract infection in patients with urinary calculi was not related the sex, intraoperative blood loss, and baric index ( $>00.05)$, and related to the age, operation time, postoperative indwelling catheter time, stone size, and preoperative prophylactic use of antibiotics $(\mathrm{p}<0.05)$ (Table 4).

To explore the independent risk factors of urinary tract infection, multivariate logistic regression analysis was used to analyze the related factors obtained by univariate analysis. Multivariate logistic regression analysis showed that the age ( $\geq 65 \mathrm{y}$ old), operation time ( $\geq 60 \mathrm{~min}$ ), postoperative indwelling catheter time $(\geq 7 \mathrm{~d})$, and no preoperative prophylactic use of antibiotics were the risk factors of postoperative urinary tract infection in patients with urinary calculi $(\mathrm{p}<0.05)$ (Table 5).

Urinary tract infection was an inflammatory reaction caused by the invasion of bacteria and fungus in urine, which was easily induced by external factors, such as long-term indwelling catheter after operation, poor wound care $^{[10]}$. Perioperative urinary tract infection must be controlled when the urinary calculi patients were treated with surgical treatment, otherwise, it was easy to affect the postoperative recovery of patients,

TABLE 1: THE COMPOSITION OF THE FLORA

\begin{tabular}{|c|c|c|c|}
\hline Classification & Pathogens & Number & Percentage (\%) \\
\hline \multirow{5}{*}{ Gram-positive bacteria $(n=34)$} & Staphylococcus aureus & 79 & 12.60 \\
\hline & Enterococcus faecium & 35 & 5.61 \\
\hline & Enterococcus faecalis & 34 & 5.45 \\
\hline & Staphylococcus epidermidis & 21 & 3.37 \\
\hline & Acinetobacter baumannii & 45 & 7.21 \\
\hline \multirow{3}{*}{ Gram-negative bacteria $(n=78)$} & Escherichia coli & 148 & 23.72 \\
\hline & Klebsiella pneumonia & 74 & 11.86 \\
\hline & Pseudomonas aeruginosa & 64 & 10.26 \\
\hline \multirow{3}{*}{ Fungus $(n=14)$} & Proteus mirabilis & 55 & 8.81 \\
\hline & Candida tropicalis & 50 & 8.00 \\
\hline & Candida albicans & 19 & 3.01 \\
\hline
\end{tabular}

TABLE 2: ANTIMICROBIAL RESISTANCE SPECTRUM OF GRAM-POSITIVE BACTERIA

\begin{tabular}{|c|c|c|c|c|c|c|c|c|}
\hline \multirow{2}{*}{ Antibacterials } & \multicolumn{2}{|c|}{$\begin{array}{l}\text { Staphylococcus aureus } \\
\qquad(\mathrm{n}=79)\end{array}$} & \multicolumn{2}{|c|}{$\begin{array}{l}\text { Enterococcus faecium } \\
\qquad(\mathrm{n}=35)\end{array}$} & \multicolumn{2}{|c|}{$\begin{array}{l}\text { Enterococcus faecalis } \\
\qquad(\mathrm{n}=34)\end{array}$} & \multicolumn{2}{|c|}{$\begin{array}{c}\text { Staphylococcus } \\
\text { epidermidis }(n=21)\end{array}$} \\
\hline & Number & $\begin{array}{l}\text { Resistance } \\
\text { rate }(\%)\end{array}$ & Number & $\begin{array}{c}\text { Resistance } \\
\text { rate (\%) }\end{array}$ & Number & $\begin{array}{c}\text { Resistance } \\
\text { rate (\%) }\end{array}$ & Number & $\begin{array}{c}\text { Resistance } \\
\text { rate (\%) }\end{array}$ \\
\hline Rifampicin & 7 & 8.86 & 21 & 60.00 & 14 & 41.18 & 6 & 28.57 \\
\hline Gentamicin & 43 & 54.43 & 25 & 71.43 & 8 & 23.53 & 11 & 52.38 \\
\hline Ciprofloxacin & 21 & 26.58 & 27 & 77.14 & 18 & 52.94 & 3 & 14.29 \\
\hline Erythromycin & 67 & 84.81 & 34 & 97.14 & 33 & 97.06 & 21 & 100.00 \\
\hline Azithromycin & 25 & 31.65 & 14 & 40.00 & 5 & 14.71 & 14 & 66.67 \\
\hline Penicillin sodium & 55 & 69.62 & 16 & 45.71 & 21 & 61.76 & 12 & 57.14 \\
\hline Levofloxacin & 6 & 7.59 & 6 & 17.14 & 2 & 5.88 & 1 & 4.76 \\
\hline Tetracycline & 8 & 10.13 & 14 & 40.00 & 11 & 32.35 & 11 & 52.38 \\
\hline Clindamycin & 65 & 82.28 & 32 & 91.43 & 32 & 94.12 & 16 & 76.19 \\
\hline Vancomycin & 59 & 74.68 & 23 & 65.71 & 22 & 64.71 & 6 & 28.57 \\
\hline
\end{tabular}


www.ijpsonline.com

TABLE 3: ANTIMICROBIAL RESISTANCE SPECTRUM OF GRAM-NEGATIVE BACTERIA

\begin{tabular}{|c|c|c|c|c|c|c|c|c|c|c|}
\hline \multirow{2}{*}{ Antibacterials } & \multicolumn{2}{|c|}{$\begin{array}{c}\text { Acinetobacter } \\
\text { baumannii }(\mathrm{n}=45)\end{array}$} & \multicolumn{2}{|c|}{$\begin{array}{l}\text { Escherichia coli } \\
(\mathrm{n}=148)\end{array}$} & \multicolumn{2}{|c|}{$\begin{array}{c}\text { Klebsiella } \\
\text { pneumonia }(\mathrm{n}=74)\end{array}$} & \multicolumn{2}{|c|}{$\begin{array}{c}\text { Pseudomonas } \\
\text { aeruginosa }(n=64)\end{array}$} & \multicolumn{2}{|c|}{$\begin{array}{l}\text { Proteus mirabilis } \\
(\mathrm{n}=55)\end{array}$} \\
\hline & Number & $\begin{array}{l}\text { Resistance } \\
\text { rate (\%) }\end{array}$ & Number & $\begin{array}{c}\text { Resistance } \\
\text { rate (\%) }\end{array}$ & Number & $\begin{array}{l}\text { Resistance } \\
\text { rate (\%) }\end{array}$ & Number & $\begin{array}{c}\text { Resistance } \\
\text { rate (\%) }\end{array}$ & Number & $\begin{array}{c}\text { Resistance } \\
\text { rate (\%) }\end{array}$ \\
\hline Cefuroxime & 35 & 77.78 & 106 & 71.62 & 62 & 83.78 & 62 & 96.88 & 51 & 92.73 \\
\hline Cefoxitin & 29 & 64.44 & 74 & 50.00 & 37 & 50.00 & 23 & 35.94 & 32 & 58.18 \\
\hline Ceftazidime & 27 & 60.00 & 81 & 54.73 & 27 & 36.49 & 52 & 81.25 & 31 & 56.36 \\
\hline Cefotaxime & 20 & 44.44 & 85 & 57.43 & 28 & 37.84 & 30 & 46.88 & 21 & 38.18 \\
\hline Amoxicillin & 43 & 95.56 & 142 & 95.95 & 73 & 98.65 & 63 & 98.44 & 43 & 78.18 \\
\hline Ciprofloxacin & 37 & 82.22 & 112 & 75.68 & 60 & 81.08 & 37 & 57.81 & 41 & 74.55 \\
\hline Etimicin & - & 0.00 & 88 & 59.46 & 20 & 27.03 & - & - & 10 & 18.18 \\
\hline Amikacin & 7 & 15.56 & 4 & 2.70 & 17 & 22.97 & 5 & 7.81 & 1 & 1.82 \\
\hline Gentamicin & 21 & 46.67 & 82 & 55.41 & 50 & 67.57 & 46 & 71.88 & 25 & 45.45 \\
\hline Meropenem & 8 & 17.78 & 4 & 2.70 & 3 & 4.05 & 2 & 3.13 & 6 & 10.91 \\
\hline Levofloxacin & 31 & 68.89 & 102 & 68.92 & 56 & 75.68 & 49 & 76.56 & 37 & 67.27 \\
\hline
\end{tabular}

TABLE 4: UNIVARIATE ANALYSIS OF POSTOPERATIVE URINARY TRACT INFECTION IN PATIENTS WITH URINARY CALCULI

\begin{tabular}{|c|c|c|c|c|c|c|}
\hline Factors & & Cases & $\begin{array}{l}\text { Urinary tract } \\
\text { infection }\end{array}$ & $\begin{array}{l}\text { Without urinary } \\
\text { tract infection }\end{array}$ & $\mathrm{X}^{2}$ & $\mathrm{p}$ \\
\hline \multirow{2}{*}{ Age } & $\geq 65$ & 203 & 153 & 50 & \multirow{2}{*}{16.345} & \multirow{2}{*}{0.001} \\
\hline & $<65$ & 214 & 81 & 133 & & \\
\hline \multirow[b]{2}{*}{ Sex } & Male & 189 & 106 & 73 & \multirow{2}{*}{0.937} & \multirow{2}{*}{0.538} \\
\hline & Female & 228 & 128 & 110 & & \\
\hline \multirow{2}{*}{ Intraoperative blood loss } & $\geq 100 \mathrm{ml}$ & 157 & 88 & 75 & \multirow{2}{*}{0.855} & \multirow{2}{*}{0.641} \\
\hline & $<100 \mathrm{ml}$ & 260 & 124 & 136 & & \\
\hline \multirow{2}{*}{ Stone size } & $\geq 3 \mathrm{~cm}$ & 192 & 147 & 45 & \multirow{2}{*}{4.102} & \multirow{2}{*}{0.042} \\
\hline & $<3 \mathrm{~cm}$ & 215 & 86 & 129 & & \\
\hline \multirow{2}{*}{ Operation time } & $\geq 60 \mathrm{~min}$ & 145 & 97 & 48 & \multirow{2}{*}{6.391} & \multirow{2}{*}{0.012} \\
\hline & $<60 \mathrm{~min}$ & 272 & 137 & 135 & & \\
\hline \multirow{2}{*}{ Postoperative indwelling catheter time } & $\geq 7 \mathrm{~d}$ & 152 & 118 & 34 & \multirow{2}{*}{10.237} & \multirow{2}{*}{0.001} \\
\hline & $<7 \mathrm{~d}$ & 265 & 116 & 149 & & \\
\hline \multirow{2}{*}{$\begin{array}{l}\text { Preoperative prophylactic use of } \\
\text { antibiotics }\end{array}$} & Yes & 268 & 108 & 160 & \multirow[t]{2}{*}{7.787} & \multirow[t]{2}{*}{0.007} \\
\hline & No & 149 & 126 & 23 & & \\
\hline \multirow{2}{*}{ Baric index } & $\geq 20 \mathrm{~kg} / \mathrm{m}^{2}$ & 253 & 140 & 113 & \multirow{2}{*}{0.751} & \multirow{2}{*}{0.793} \\
\hline & $<20 \mathrm{~kg} / \mathrm{m}^{2}$ & 164 & 94 & 70 & & \\
\hline
\end{tabular}

and even cause life-threatening inflammatory reactions such as urinary tract obstruction ${ }^{[11,12]}$.

In this study, through the isolation, culture, and identification of pathogens in the midstream urine of urinary calculi patients complicated with urinary tract infection, it was found that the main pathogens causing urinary tract infection were gram-negative bacteria, gram-positive bacteria, and fungus. Escherichia coli were the most common bacteria in gram-negative bacteria, which may be related to the fact that the cilium on the cell wall of Escherichia coli can specifically recognize the specific receptors on urothelial cells. Escherichia coli can adhere to the surface of urinary transitional epithelium for retention and reproduction, thus inducing infection. Through the drug sensitivity test, it was found that the resistance rate of gram-negative bacteria to cefuroxime, amoxicillin, ciprofloxacin, and levofloxacin was high, which was consistent with the existing research ${ }^{[13,14]}$. It may be related to the frequent use of these drugs in the clinic.

Staphylococcus aureus (belongs to staphylococcus) was the most common bacteria in gram-positive bacteria, and the most common bacteria causing inflammation, which distributes widely and has strong infectivity. In some studies, it was found that the most infectious pathogens in gram-positive bacteria were Enterococcus faecium and Enterococcus faecalis, which was not consistent with the results of this study, it may be caused by the regional reasons ${ }^{[15,16]}$. The results of the drug sensitivity tests showed that the resistance rate of gram- 
TABLE 5: MULTIVARIATE LOGISTIC REGRESSION ANALYSIS OF POSTOPERATIVE URINARY TRACT INFECTION IN PATIENTS WITH URINARY CALCULI

\begin{tabular}{lcccccc}
\hline Factors & $\begin{array}{c}\text { Regression } \\
\text { coefficient }\end{array}$ & SD & $\mathrm{X}^{2}$ & $\mathrm{p}$ & $\begin{array}{c}\text { Odds ratio } \\
\text { (OR) }\end{array}$ & $\begin{array}{c}\text { 95\% Confidence } \\
\text { intervals (Cl) }\end{array}$ \\
\hline Operation time & 1.104 & 0.512 & 6.341 & 0.017 & 3.956 & $1.236-10.536$ \\
Postoperative indwelling catheter time & 1.053 & 0.526 & 5.732 & 0.028 & 2.931 & $1.185-9.321$ \\
Preoperative prophylactic use of antibiotics & 1.027 & 0.439 & 8.255 & 0.004 & 5.762 & $1.978-14.373$ \\
Age & 1.464 & 0.616 & 7.395 & 0.009 & 4.389 & $1.783-11.552$ \\
Stone size & 1.537 & 0.507 & 2.181 & 0.093 & 2.105 & $0.897-10.255$ \\
\hline
\end{tabular}

positive bacteria to clindamycin and erythromycin was the highest, and the resistance rate of Staphylococcus epidermidis to erythromycin was $100.00 \%$. The reason may be closely related to the hospital drug management and clinical antibiotic abuse, thus we should pay more attention to the clinical drug management.

Univariate analysis showed that the postoperative urinary tract infection in patients with urinary calculi was related to the age, operation time, postoperative indwelling catheter time, stone size, and preoperative prophylactic use of antibiotics. Multivariate logistic regression analysis showed that the age ( $\geq 65 \mathrm{y}$ old), operation time ( $\geq 60 \mathrm{~min})$, postoperative indwelling catheter time ( $\geq 7 \mathrm{~d}$ ), and no preoperative prophylactic use of antibiotics were the risk factors of postoperative urinary tract infection in patients with urinary calculi $(p<0.05)$. With the increase of age, the immune function and the ability of tissues/organs of patients decreased rapidly, thus they were more likely to have urinary tract infection after the operation. The long operation time was very harmful to the human body, which significantly increased the recovery time of the human body. At the same time, surgical trauma also brings the risk of infection, which greatly increases the risk of urinary tract infection. The postoperative indwelling drainage tube may damage the mucous membrane of the urethra and reduce the defense ability ${ }^{[17]}$, and the long indwelling time was easy to increase the risk of external pathogens entering the urethra, which was more likely to induce urinary tract infection. It has been reported that the asymptomatic bacteriuria was a major cause of urethral infection ${ }^{[18]}$, thus the prophylactic use of antibiotics before the operation can kill bacteria effectively and reduce the risk of urinary tract infection.

In a word, urinary calculi patients were prone to urinary tract infection after the operation, and the main pathogens were gram-negative bacteria and grampositive bacteria, and they were seriously resistant to some drugs. Antibiotics should be reasonably selected according to the risk factors of urinary tract infection and the results of the drug sensitivity tests to avoid further aggravation of bacterial drug resistance.

\section{Acknowledgements:}

This work was supported by Shaoxing People's Hospital.

\section{Conflict of Interests:}

The authors declared no conflict of interest.

\section{REFERENCES}

1. Bashir M, Umar AB, Bilyaminu M. Determination of bacteria associated with urinary catheters from patients suffering from urinary tract infections. Dr. Sulaiman Al Habib Med J 2020;2(1):20-3.

2. De Lorenzis E, Alba AB, Cepeda M, Galan JA, Geavlete P, Giannakopoulos S, et al. Bacterial spectrum and antibiotic resistance of urinary tract infections in patients treated for upper urinary tract calculi: a multicenter analysis. Eur J Clin Microbiol Infect Dis 2020;39(10):1971-81.

3. Fa-wen DE. Drug resistance and distribution of pathogenic bacteria causing urinary tract infections. Chin J Nosocomiol 2012;17.

4. Shi $\mathrm{H}, \mathrm{Xu} \mathrm{SX}, \mathrm{Li} \mathrm{K}$, Luo XR, Bai XF, Wang YL, et al. Distribution and drug resistance of pathogenic bacteria causing urinary tract infections in hospitalized patients of department of urology. Chin J Nosocomiol 2013;14.

5. Jiang SL, Qu YJ, Zhao Q, Xi M, Zhang HY. Distribution and drug resistance of pathogenic bacteria isolated from diabetic patient with urinary tract infection in our hospital in 2011. Chin Pharm 2013;2.

6. Yu-Jie L, Jing-Quan LI. Drug resistance of pathogenic bacteria causing hospital-acquired urinary tract infection. Chin J Nosocomiol 2011;21:589-91.

7. Liu $\mathrm{F}, \mathrm{Wu} \mathrm{CB}$, Qin LY. Investigation on distribution and drug resistance of urinary tract infecting pathogenic bacteria. Int $\mathrm{J}$ Lab Med 2006(11):13.

8. De-Ming S, Qian-Jin Z, Zhi-Qiang X. Constituent ratio of species and drug-resistance of pathogenic bacteria causing urinary tract infections in senile patients. Chin J Nosocomiol 2014;24:2637-39.

9. Ding J, Ying Q, Yang L, Song X. Pathogenic Bacteria in Urinary Tract Infection after Cesarean Section: Their Distribution and Drug Resistance. Chin J Nosocomiol 2009.

10. Hua-Fen W. The study on pathogenic bacteria status and bacterial drug-resistance of urinary tract infections in recent five years. Pract J Med Pharm 2006.

11. Bing-Yong Q. Analysis of distribution and drug resistance of pathogenic bacteria in urinary tract infections in our hospital. Clin Res Pract 2019.

12. LIU Yu. Distribution and resistance of pathogenic bacteria in 
www.ijpsonline.com

patients with nosocomial urinary tract infections. J Clin Pulm Med 2015.

13. Xiang-Qun C, Qing-Lian G, Xiao-Ning L. Pathogenic bacteria culture and drug resistance analysis in urinary tract infections in senile diabetics. Lab Med Clin 2016.

14. Stamey TA, Pfau A. Urinary infections: a selective review and some observations. Calif Med 1970;113(6):16.

15. Togan T, Azap OK, Durukan E, Arslan H. The prevalence, etiologic agents and risk factors for urinary tract infection among spinal cord injury patients. Jundishapur J Microbiol 2014;7(1)
16. Rong Z, Xi C, Ya-Hong XU. Distribution and antimicrobial resistance of pathogens in urinary tract infections. J Tongji Univ (Med sci) 2016.

17. Adwan K, Abu-Hasan N, Adwan G, Jarrar N, Abu-Shanab B, Abu-Zant A. Nosocomial infection caused by methicillinresistant Staphylococcus aureus in Palestine. Microb Drug Resist 2005;11(1):75-7.

18. Boya C. Distribution and drug resistance of pathogens causing urinary tract infections in diabetic nephropathy. Contemp Med 2019 . 